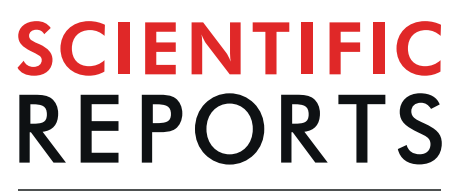

natureresearch

\title{
Immunoproteomic analysis of Borrelia miyamotoi for the identification of serodiagnostic antigens
}

\author{
Emma K. Harris' ${ }^{1}$, Marisa R. Harton ${ }^{2}$, Maria Angela de Mello Marques ${ }^{2}$, John T. Belisle ${ }^{2}$, \\ Claudia R. Molins ${ }^{1}$, Nicole Breuner ${ }^{1}$, Gary P. Wormser ${ }^{3}$ \& Robert D. Gilmore ${ }^{1 *}$
}

The tick-borne spirochete, Borrelia miyamotoi, is an emerging pathogen of public health significance. Current $B$. miyamotoi serodiagnostic testing depends on reactivity against $\mathrm{GlpO}$ which is not highly sensitive on acute phase serum samples. Additionally, anti-B. miyamotoi antibodies can cross-react with $\mathrm{C} 6$ antigen testing for $B$. burgdorferi, the causative agent of Lyme disease, underscoring the need for improved serological assays that produce accurate diagnostic results. We performed an immunoproteomics analysis of $B$. miyamotoi proteins to identify novel serodiagnostic antigens. Sera from mice infected with $B$. miyamotoi by subcutaneous inoculation or tick bite were collected for immunoblotting against $B$. miyamotoi membrane-associated proteins separated by 2 -dimensional electrophoresis (2DE). In total, 88 proteins in $402 \mathrm{DE}$ immunoreactive spots were identified via mass spectrometry. Multiple variable large proteins (Vlps) and a putative lipoprotein were among those identified and analyzed. Reactivity of anti-B. miyamotoi sera against recombinant Vlps and the putative lipoprotein confirmed their immunogenicity. Mouse anti-B. burgdorferi serum was cross-reactive to all recombinant Vlps, but not against the putative lipoprotein by IgG. Furthermore, antibodies against the recombinant putative lipoprotein were present in serum from a $B$. miyamotoi-infected human patient, but not a Lyme disease patient. Results presented here provide a comprehensive profile of $B$. miyamotoi antigens that induce the host immune response and identify a putative lipoprotein as a potentially specific antigen for $B$. miyamotoi serodetection.

The tick-borne spirochete Borrelia miyamotoi is an emergent pathogen of worldwide public health importance. Despite its phylogenetic grouping with relapsing fever Borrelia (RFB), which are transmitted by argasid (or soft) ticks, B. miyamotoi is transmitted by ixodid (or hard) tick species. In North America, vectors include Ixodes scapularis and I. pacificus, which are also hosts for the causative agent of Lyme disease (LD), Borrelia burgdorferi. Prevalence in ticks ranges from 0.02 to $10 \%$ in I. scapularis and Ixodes pacificus populations in the United States $^{1-4}$. Though the true burden of B.miyamotoi disease (BMD) on human disease is still being realized, current research has estimated human prevalence to be approximately $0.84-17 \%$ among individuals parasitized by ticks ${ }^{1,3,5-8}$. Symptoms associated with BMD are often non-specific, complicating diagnosis in endemic locations with high LD incidence ${ }^{9,10}$. Furthermore, there remains a relative paucity of information regarding immunogenic characterization for B. miyamotoi infection in vertebrate hosts.

To date, sensitive and specific serology-based diagnostics for BMD are experimental, lacking in commercial validation and production. Laboratory serodiagnostics target the B. miyamotoi antigen glycerophosphodiester phosphodiesterase (GlpQ), a gene product present in RFB but absent in Lyme Borrelia. However, weak antibody response against GlpQ has been reported in a number of confirmed BMD cases, particularly acute phase serum samples ${ }^{5,11,12}$. Recent studies have suggested that serodiagnostic sensitivity for BMD can be improved by assaying GlpQ reactivity in conjunction with variable major proteins (Vmps) (i.e. variable large and small proteins) ${ }^{13,14}$. Vmps are responsible for the multiphasic antigenic variation that produces fever relapses characteristic of RFB

${ }^{1}$ Bacterial Diseases Branch, Division of Vector-Borne Diseases, National Center for Emerging and Zoonotic Infectious Diseases, Centers for Disease Control and Prevention, Fort Collins, CO, USA. ${ }^{2}$ Department of Microbiology, Immunology and Pathology, Colorado State University, Fort Collins, CO, USA. ${ }^{3}$ Department of Medicine, Division of Infectious Disease, New York Medical College, Valhalla, NY, USA. *email: rbg9@cdc.gov 


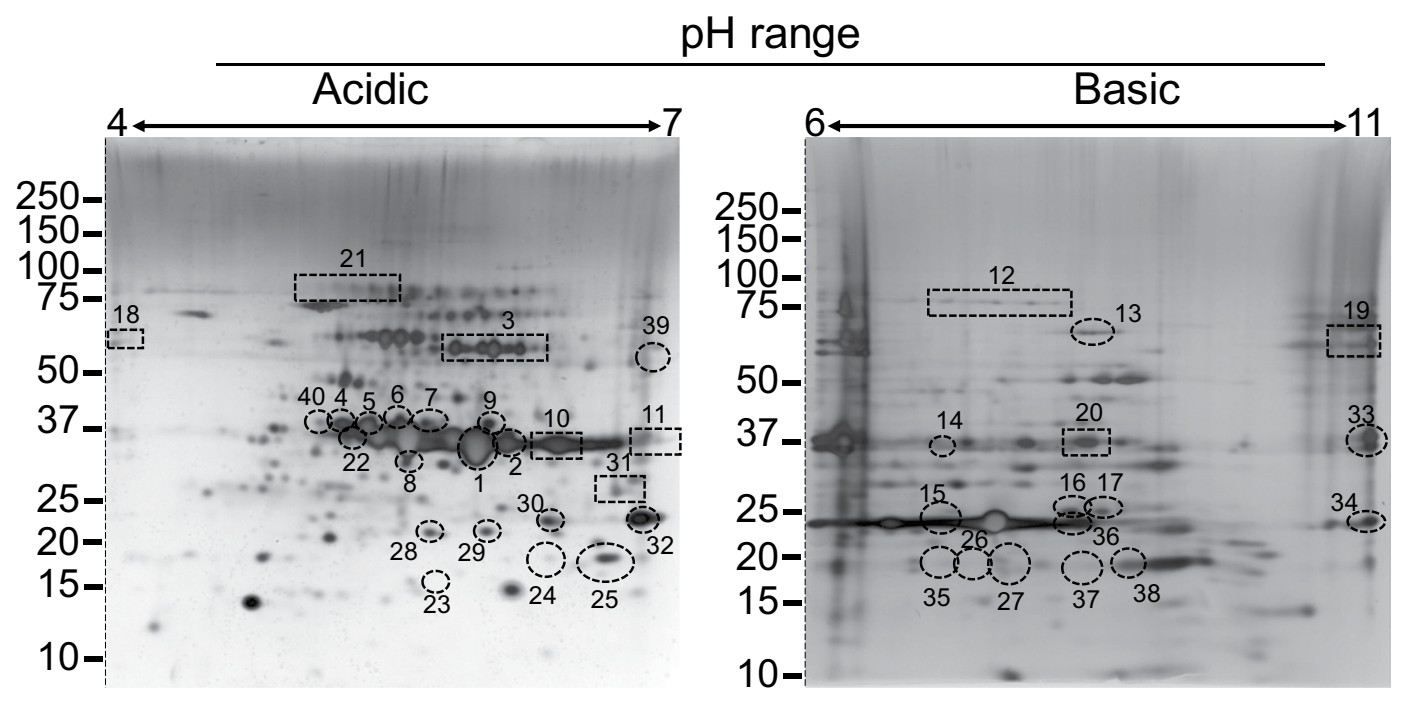

Figure 1. Silver stain representation of B. miyamotoi LB-2001 membrane-associated proteins. A defined spot profile was established by using approximately $100 \mu \mathrm{g}$ of protein applied to IPG strips for IEF across $\mathrm{pH} 4-7$ and 6-11. Second dimension 4-12\% SDS-PAGE separated proteins by molecular weight (denoted by $\mathrm{kDa}$ on left of panels). Immunoreactive protein spots against antibodies present in B. miyamotoi-infected murine hosts are circled and numbered with corresponding identities listed in Table 1 and Supplemental Table 1. Dashed lines demarcate where the gel has been cropped to exclude molecular weight markers. Uncropped gel images can be viewed in Supplemental Fig. 2.

infections ${ }^{15}$. However, antibodies produced against Vmps may be susceptible to cross-reactivity with the orthologous B. burgdorferi protein Vmp-like sequence expressed (VlsE), which comprises the sensitive C6 antigen used for LD testing ${ }^{16,17}$. A recent retrospective study highlighted that serum from 22 of 24 (91.7\%) BMD-positive patients possessed cross-reactive antibodies to the C6 antigen ${ }^{12}$. Therefore, we hypothesized that a comprehensive immunoproteomic analysis of the host antibody response against B. miyamotoi infection would reveal unique antigens to augment GlpQ and Vmps for improved serodiagnostic detection of BMD.

In this study, antiserum from B. miyamotoi-infected mice applied to immunoblots of B. miyamotoi proteins separated by 2 -dimensional electrophoresis (2DE) defined the immunogenic protein profile of this pathogen. Mass spectrometry was used to identify putative serum-reactive proteins leading to the identification of a novel lipoprotein antigen with the potential to differentiate BMD from LD. These analyses demonstrate considerable variability in the antibody response between mice infected via subcutaneous inoculation and tick bite, as well as across the course of infection.

\section{Results}

B. miyamotoi-infected murine hosts elicit an immune response against multiple proteins regardless of inoculation route. B. miyamotoi membrane-associated proteins were purified, fractionated by $2 \mathrm{DE}$ (Fig. 1), and subjected to immunoblotting with antiserum from mice infected by either needle inoculation or tick bite and sacrificed at 8 or 40 days. Proteins corresponding to the immunoreactive spots from the blots were identified by mass spectrometry. Protein identifications for each spot noted below are listed in Table 1 and corresponding raw data are located in Supplemental Table 1.

Acute IgM antibody response from needle inoculated mice at 8 days post-inoculation (dpi) resulted in two reactive spots constituting 10 protein identities: VlpC2, Vlp5, VlpD2, flagellin, a flagellar protein, GlpQ, phosphate $\mathrm{ABC}$ transporter substrate-binding protein, $60 \mathrm{kDa}$ chaperonin, ornithine carbamoyltransferase, and phosphoglycerate kinase (Fig. 2a; Table 1). IgM immunoblotting with serum collected at 8 dpi derived from tick bite inoculation reacted with 17 immunogenic spots representing 47 protein identities (Fig. 2b; Table 1). This included immunoreactive spots number 1 and 2 which were recognized by serum at 8 dpi across both needle and tick bite inoculation routes. Identification of additional proteins recognized by mouse serum from $8 \mathrm{dpi}$ via tick bite included proteins assigned the following gene ontology associations: membrane (VlpD8, VlpD9, Vlp 15/16, VlpD1, VlpD10, Vlp, and Vsp1); flagellum associated; ATPase and ATP-binding; protein binding; double-stranded RNA binding; translation associated; GTP-binding; metabolic processes; cell morphogenesis; proteolysis; transcription associated; polyamine binding; and unassigned (including uncharacterized proteins and a putative lipoprotein) (Fig. 2b; Table 1).

The largest number of immunoreactive spots was observed with sera collected at $40 \mathrm{dpi}$ (IgG). Spots 1-11 and 14-17, originally detected at $8 \mathrm{dpi}$, were again observed at this time point including nine Vlps and Vsp1 (Fig. 3). Twenty-three spots were uniquely observed with sera from $40 \mathrm{dpi}$. Eight of the 23 unique spots $(21,22,24,25$, $26,27,33$, and 40 ) were detected across immunoblots probed with both needle and tick bite inoculated mouse serum of which protein identities were assigned the following gene ontology associations: membrane (multiple Vlps and Vsp1); flagellum associated; phosphoric diester hydrolase activity (GlpQ); ATPase and ATP-binding; 


\begin{tabular}{|c|c|c|c|c|c|c|}
\hline GO term ${ }^{\mathrm{a}}$ & Spot no. & Protein ID & $\mathrm{pI}^{\mathrm{b}}$ & $\begin{array}{l}\text { NCBI accession } \\
\text { ID }\end{array}$ & $\begin{array}{l}\text { Pred MW } \\
\text { in } \mathrm{kDa}^{\mathrm{c}}\end{array}$ & No. of unique peptides \\
\hline \multicolumn{7}{|c|}{ CC $C^{\text {d: Membrane }}$} \\
\hline & $1,3,10,11,22,31,32,39,40$ & $\mathrm{VlpC}^{\mathrm{g}}$ & 5.84 & ALU64348.1 & 35 & $26,5,28,24,14,5,9,4,4$ \\
\hline & 2 & Vlp5 $5^{g}$ & 5.73 & AOW96300.1 & 35 & 2 \\
\hline & $2,4,5,6,7,22,33$ & VlpD2g $^{g}$ & 5.55 & ALM31567.1 & $34^{*}$ & $3,5,9,14,5,12,4$ \\
\hline & $4,5,6,7,9,22,33$ & VlpD8g $^{g}$ & 5.43 & ALU64349.1 & $33^{*}$ & $29,32,22,7,5,16,7$ \\
\hline & $4,5,6,7,9,10,22$ & VlpD9g & 5.96 & ALU64350.1 & $34^{*}$ & $2,3,5,9,18,2,2$ \\
\hline & $4,5,6,7,22$ & Vlp15/16 & 5.61 & AOW96282.1 & $33^{*}$ & $5,7,7,5,3$ \\
\hline & $4,5,6,22$ & VlpD1g & 5.62 & ALM31565.1 & 34 & $4,8,11,8$ \\
\hline & $5,6,7,9,22$ & VlpD10g & 5.77 & ALU64352.1 & $33^{*}$ & $2,3,15,4,2$ \\
\hline & $14,16,20,33,38$ & Vlp ${ }^{g}$ & 5.87 & AOW96324.1 & $33^{*}$ & $10,4,7,14,2$ \\
\hline & 22 & Vlpg & 5.89 & AOW96302.1 & 34 & 5 \\
\hline & $\begin{array}{l}6,10,11,15,16,17,2025,26 \\
27,30,31,32,34,35,36\end{array}$ & Vsp1 $1^{\mathrm{h}}$ & 6.18 & AJA67245.2 & 22 & $\begin{array}{l}3,3,5,8,4,4,2,11,3,4 \\
20,5,20,6,2,11\end{array}$ \\
\hline & 11 & HflK & 5.79 & AGT27198.1 & 35 & 8 \\
\hline & 11 & HflC & 9.52 & AGT27199.1 & 37 & 8 \\
\hline & 23 & DUF1640 domain-containing protein & 5.42 & AOW96294.1 & 18 & 3 \\
\hline & 18 & Ribonuclease Y & 7.65 & AGT27464.1 & 58 & 3 \\
\hline \multicolumn{7}{|c|}{ CC $^{\mathrm{d}}$ : flagellum associated } \\
\hline & $\begin{array}{l}1,2,4,5,6,7,8,9,10,11,21 \\
22,30,32,33\end{array}$ & Flagellin & 5.36 & AGT27144.1 & 35 & $\begin{array}{l}11,13,9,10,12,11,12,10 \\
11,10,10,13,11,10,12\end{array}$ \\
\hline & $6,22,33$ & Flagellar assembly protein-FliH & 5.28 & AGT27286.1 & 35 & $14,3,3$ \\
\hline & 28 & Flagellar protein & 5.33 & AGT27283.1 & 24 & 2 \\
\hline & $2,11,14$ & Flagellar protein & 8.38 & AGT27611.1 & 39 & $10,2,3$ \\
\hline & 23 & Flagellar hook assembly protein-FlgD & 5.49 & AGT27281.1 & 16 & 2 \\
\hline & 38 & Flagellar basal-body rod protein-FlgC & 8.92 & AGT27290.1 & 17 & 2 \\
\hline & 40 & Flagellar motor switch protein-FliM & 5.09 & AGT27275.1 & 39 & 2 \\
\hline \multicolumn{7}{|c|}{ MFe : phosphoric diester hydrolase activity } \\
\hline & $1,2,5,6,8,11,22$ & $\mathrm{GlpQ}^{\mathrm{i}}$ & 5.68 & AGT27237.1 & 39 & $16,10,2,13,9,11,15$ \\
\hline \multicolumn{7}{|c|}{ MFe: ATPase and ATP binding } \\
\hline & 1,31 & $\begin{array}{l}\text { Phosphate } \mathrm{ABC} \text { transporter substrate-binding } \\
\text { protein }\end{array}$ & 6.92 & AGT27210.1 & 31 & 2,13 \\
\hline & $2,4,5,7,8,19,22$ & $60 \mathrm{kDa}$ chaperonin & 5.28 & AGT27591.1 & 59 & $5,10,4,2,4,3,8$ \\
\hline & 3,18 & $\mathrm{ABC}$ transporter substrate binding protein & 6.11 & AGT27324.1 & 61 & 32,19 \\
\hline & $3,18,19$ & $\mathrm{ABC}$ transporter substrate binding protein & 5.90 & AGT27323.1 & 61 & $18,12,4$ \\
\hline & 8,21 & Chaperone DnaK & 5.00 & AGT27477.1 & 69 & 7,40 \\
\hline & 10,11 & ATP-dependent zinc metalloprotease-FtsH & 8.61 & AGT27731.1 & 71 & 2,2 \\
\hline & 11 & $\begin{array}{l}\text { Holliday junction ATP-dependent DNA helicase- } \\
\text { RuvB }\end{array}$ & 7.04 & AGT27027.1 & 38 & 2 \\
\hline & 11 & ATPase & 6.39 & AGT27171.1 & 37 & 17 \\
\hline & $11,20,22$ & ABC-transporter binding protein & 9.26 & AGT27698.1 & 35 & $11,2,2$ \\
\hline & 28,29 & V-type protein ATPase subunit E & 5.49 & AGT27099.1 & 23 & 10,10 \\
\hline & 31 & Phosphate import ATP-binding protein-PstB & 6.22 & AGT27213.1 & 29 & 9 \\
\hline & 39 & $\begin{array}{l}\text { ATP-dependent Clp protease ATP-binding subunit- } \\
\text { ClpX }\end{array}$ & 7.97 & AGT27557.1 & 48 & 2 \\
\hline \multicolumn{7}{|c|}{$M^{e}$ : protein binding } \\
\hline & 8,31 & Uncharacterized protein & 8.33 & WP_082002168.1 & 30 & 2,4 \\
\hline \multicolumn{7}{|c|}{$\begin{array}{l}\text { MFe: catalytic } \\
\text { activity }\end{array}$} \\
\hline & 31 & Triosephosphate isomerase-TpiA & 6.23 & AGT27058.1 & 28 & 13 \\
\hline & 32 & $\begin{array}{l}\text { 5'-methylthioadenosine/S-adenoslyhomocystein } \\
\text { nucleosidase }\end{array}$ & 5.97 & WP_082583095.1 & 25 & 5 \\
\hline & 39 & Pyruvate kinase & 6.18 & AGT27339.1 & 53 & 21 \\
\hline & 39 & Inosine-5'-monophosphate dehydrogenase-GuaB & 8.48 & AJA67229.1 & 53 & 7 \\
\hline \multicolumn{7}{|c|}{ MFe: double-stranded RNA binding } \\
\hline & 11 & Threonylcarbamoyl-AMP synthase & 9.35 & AGT27679.1 & 38 & 4 \\
\hline \multicolumn{7}{|c|}{ MF $^{\text {e }}$ translation associated } \\
\hline & $15,30,32$ & $50 \mathrm{~S}$ ribosomal protein-L25 & 6.77 & AGT27728.1 & 21 & $3,2,6$ \\
\hline & 18 & Lysine-tRNA ligase & 8.90 & AGT27602.1 & 61 & 8 \\
\hline \multicolumn{7}{|c|}{ Continued } \\
\hline
\end{tabular}




\begin{tabular}{|c|c|c|c|c|c|c|}
\hline GO term ${ }^{\mathrm{a}}$ & Spot no. & Protein ID & $\mathrm{pI}^{\mathrm{b}}$ & $\begin{array}{l}\text { NCBI accession } \\
\text { ID }\end{array}$ & $\begin{array}{l}\text { Pred MW } \\
\text { in } \mathrm{kDa}^{\mathrm{c}}\end{array}$ & No. of unique peptides \\
\hline & 23,25 & $30 \mathrm{~S}$ ribosomal protein-S10 & 10.05 & AGT27452.1 & 12 & 2,2 \\
\hline & 24 & Elongation factor G & 5.50 & AGT27495.1 & 77 & 2 \\
\hline & 25 & 50 S ribosomal protein L21 & 9.70 & AGT27721.1 & 12 & 4 \\
\hline & 26,27 & $50 \mathrm{~S}$ ribosomal protein L5 & 9.60 & AGT26990.1 & 20 & 2,4 \\
\hline & $26,27,35$ & $50 \mathrm{~S}$ ribosomal protein L9 & 9.62 & AGT27115.1 & 19 & $4,4,2$ \\
\hline & 32 & $50 \mathrm{~S}$ ribosomal protein $\mathrm{L} 3$ & 9.83 & AGT26984.1 & 23 & 2 \\
\hline & 37 & 50S ribosomal protein L19 & 10.23 & AGT27642.1 & 17 & 2 \\
\hline & 38 & $30 \mathrm{~S}$ ribosomal protein $\mathrm{S} 7$ & 9.99 & AGT26980.1 & 18 & 2 \\
\hline \multicolumn{7}{|c|}{ MF $^{\text {e: GTP-binding }}$} \\
\hline & 7 & Ribosome-binding ATPase YchF & 5.40 & AGT27227.1 & 41 & 3 \\
\hline \multicolumn{7}{|c|}{ BPf: metabolic processes } \\
\hline & 2 & Ornithine carbamoyltransferase & 5.74 & WP_043867909.1 & 37 & 7 \\
\hline & 2 & Phosphoglycerate kinase & 5.84 & AGT27059.1 & 43 & 4 \\
\hline & $4,5,22$ & Enolase & 5.05 & AGT27330.1 & 47 & $3,2,2$ \\
\hline & $11,14,20,33$ & GAPDH $^{\mathrm{j}}$ & 8.32 & AGT27060.1 & 36 & $17,3,16,2$ \\
\hline \multicolumn{7}{|c|}{ BPf: cell morphogenesis } \\
\hline & 11 & Rod shape-determining protein & 6.86 & AGT27659.1 & 38 & 17 \\
\hline \multicolumn{7}{|c|}{$\mathrm{BP}^{\mathrm{f}}$ : proteolysis } \\
\hline & 10 & Serine protease & 8.99 & WP_082002164.1 & 53 & 3 \\
\hline & 39 & M18 family aminopeptidase & 6.03 & AGT27354.1 & 52 & 7 \\
\hline \multicolumn{7}{|c|}{ BP $^{\mathrm{f}}$ : transcription associated } \\
\hline & 18 & $\begin{array}{l}\text { Transcription termination/antitermination protein- } \\
\text { NusA }\end{array}$ & 4.74 & AGT27741.1 & 55 & 2 \\
\hline & $4,5,6,22,33$ & $\begin{array}{l}\text { DNA-directed RNA polymerase subunit alpha- } \\
\text { RpoA }\end{array}$ & 5.11 & AGT27462.1 & 38 & $17,16,15,18,3$ \\
\hline & 28,29 & $\begin{array}{l}\text { Transcription termination/antitermination protein- } \\
\text { NusG }\end{array}$ & 5.48 & AGT27376.1 & 21 & 12,6 \\
\hline \multicolumn{7}{|c|}{ BPf: polyamine binding } \\
\hline & 11 & $\begin{array}{l}\text { Spermidine/putrescine import ATP-binding } \\
\text { protein }\end{array}$ & 8.78 & AGT27580.1 & 40 & 3 \\
\hline & 22 & $\begin{array}{l}\text { Sperimidine/putrescine ABC transporter substrate- } \\
\text { binding protein }\end{array}$ & 5.46 & AGT27583.1 & 41 & 13 \\
\hline \multicolumn{7}{|c|}{$\mathrm{BP}^{\mathrm{f}}$ : protein folding } \\
\hline & 32 & Protein GrpE & 5.38 & AGT27478.1 & 21 & 4 \\
\hline \multicolumn{7}{|c|}{ BPf: chemotaxis } \\
\hline & 37,38 & $\begin{array}{l}\text { Probable chemoreceptor glutamine deamidase- } \\
\text { CheD }\end{array}$ & 8.63 & AGT27553.1 & 18 & 3,4 \\
\hline \multicolumn{7}{|l|}{ Unassigned } \\
\hline & $4,8,12,37$ & Uncharacterized protein & 8.22 & AGT27688.1 & 77 & $4,2,13,2$ \\
\hline & 6 & Uncharacterized protein & 5.63 & AOW96351.1 & 35 & 6 \\
\hline & 8 & Uncharacterized protein & 5.18 & AGT27657.1 & 30 & 5 \\
\hline & 11,20 & Uncharacterized protein & 9.02 & AGT27150.2 & 44 & 3,4 \\
\hline & 11 & Uncharacterized protein & 6.15 & AOW96199.1 & 37 & 2 \\
\hline & 11,20 & Uncharacterized protein & 8.91 & AGT27497.1 & 42 & 2,2 \\
\hline & 13 & Uncharacterized protein & 8.80 & AGT27550.1 & $67 *$ & 16 \\
\hline & 21 & Uncharacterized protein & 5.09 & AOW96138.1 & 28 & 3 \\
\hline & 22 & Uncharacterized protein & 5.15 & AOW96267.1 & 35 & 2 \\
\hline & 23 & Uncharacterized protein & 5.44 & AGT27223.1 & 15 & 5 \\
\hline & 23 & Uncharacterized protein & 5.72 & AOW96390.1 & 19 & 5 \\
\hline & 25 & Uncharacterized protein & 5.91 & AOW96369.1 & 29 & 3 \\
\hline & $23,24,25$ & Uncharacterized protein & 6.18 & AOW96394.1 & $15^{*}$ & $8,10,6$ \\
\hline & 29 & Uncharacterized protein & 8.37 & AGT27607.1 & 25 & 5 \\
\hline & 30 & Uncharacterized protein & 6.86 & AGT27219.1 & 28 & 4 \\
\hline & 32 & Uncharacterized protein & 7.66 & AGT27434.1 & 27 & 2 \\
\hline & 35 & Uncharacterized protein & 6.21 & AGT27719.1 & $18^{*}$ & 3 \\
\hline & 39 & Uncharacterized protein & 8.11 & AGT27044.1 & 59 & 3 \\
\hline & 23 & Heat-shock protein & 5.72 & WP_043867868.1 & 17 & 8 \\
\hline \multicolumn{7}{|c|}{ Continued } \\
\hline
\end{tabular}




\begin{tabular}{|c|c|c|c|c|c|c|}
\hline GO term ${ }^{a}$ & Spot no. & Protein ID & $\mathrm{pI}^{\mathrm{b}}$ & $\begin{array}{l}\text { NCBI accession } \\
\text { ID }\end{array}$ & $\begin{array}{l}\text { Pred MW } \\
\text { in } \mathrm{kDa}^{\mathrm{c}}\end{array}$ & No. of unique peptides \\
\hline & 11 & Carboxylesterase & 9.53 & AGT27588.1 & 38 & 2 \\
\hline & $16,30,36$ & Peptidoglycan-binding protein-LysM & 8.52 & AGT27318.1 & $44^{*}$ & $5,2,2$ \\
\hline & $4,5,6,8,11,22$ & Putative lipoprotein & 5.24 & ALN43426.1 & 35 & $2,3,4,3,3,13$ \\
\hline
\end{tabular}

Table 1. Protein identities corresponding to immunoreactive spots. Proteins are categorized according to common gene ontology (GO) terms as listed in UniProtKB. Each spot number (no.) corresponds respectively to the no. of unique peptides detected during protein identification. ${ }^{a} \mathrm{GO}$ terms $=$ gene ontology terms; ${ }^{b} \mathrm{pI}=$ isoelectric point; ${ }^{c}$ Pred $\mathrm{MW}=$ predicted molecular weight; ${ }^{d} \mathrm{CC}=$ cellular component; ${ }^{e} \mathrm{MF}=$ molecular function; ${ }^{f} \mathrm{BP}=$ biological process; ${ }^{g} \mathrm{Vlp}=$ variable large protein; ${ }^{h} \mathrm{Vsp}=$ Variable small protein; ${ }^{i} \mathrm{GlpQ}=$ glycerophosphodiester phosphodiesterase; ${ }^{j} \mathrm{GAPDH}=$ glyceraldehyde-3-phosphate dehydrogenase; * = predicted $\mathrm{pI}$ and MW excludes signal sequence if detected via ExPASy.

translation associated; metabolic processes; transcription associated; polyamine binding; and unassigned (including the previously identified putative lipoprotein) (Fig. 3a,b; Table 1). The remaining 15 immunoreactive spots recognized only in serum from tick bite inoculated mice represented 47 individual proteins, 18 of which had been identified within other spots across previous data points (i.e. 8 dpi needle or tick inoculated and 40 dpi needle inoculated). Twenty-nine proteins were uniquely identified in serum collected 40 days post-tick inoculation and assigned the following gene ontology associations: flagellum associated; ATPase and ATP-binding; catalytic activity; translation associated; proteolysis; transcription associated; protein folding; chemotaxis; and unassigned (Fig. 3b; Table 1).

Immunoreactivity against recombinant $B$. miyamotoi Vmps and putative lipoprotein validates antigen identity. We chose a subset of 10 antigens identified through 2DE immunoblotting to express as recombinant proteins (Table 2; Supplemental Fig. 1a,b) to validate immunoreactivity against antisera used in discovery 2DE immunoblots. Proteins identified by mass spectrometry revealed an uncharacterized protein (AOW96394.1), putative lipoprotein (ALN43426.1), GlpQ, Vsp1, VlpC2, VlpD2, VlpD1, VlpD8, VlpD9, and VlpD10 as potentially antigenic proteins with serodiagnostic utility (Table 2 ). The amino acid sequence of each B. miyamotoi protein was aligned with corresponding amino acid sequences from B. burgdorferi and B. hermsii proteins with the highest percent identity as reported by the BLASTp database (Fig. 4). All six Vlps were grouped together and aligned against a representative B. burgdorferi and B. hermsii protein (i.e. VlsE and Vlp15/16, respectively) which demonstrated the highest amino acid percent identity to any one B. miyamotoi Vlp. Amino acid alignment comparisons between B. miyamotoi Vlps and B. burgdorferi VlsE (Accession CAH61549.1) and B. hermsii Vlp 15/16 (Accession AAB17735.1) revealed that the six B. miyamotoi Vlps displayed 36-39\% amino acid sequence identity with the $B$. burgdorferi VlsE protein and were approximately $76-84 \%$ identical to various B. hermsii Vlps (Fig. 4a; Table 2). Vsp1 shared $46 \%$ amino acid identity to B. burgdorferi OspC (Accession $\mathrm{AAB} 86545.1$ ) and $62 \%$ to a $B$. hermsii variable outer membrane protein (Accession AHH04378.1) (Fig. 4b; Table 2). The B. miyamotoi putative lipoprotein amino acid sequence was $39 \%$ identical to a $B$. burgdorferi putative lipoprotein (Accession AAC67199.1) and 62\% to an uncharacterized B. hermsii protein (Accession AHH04480.1) (Fig. 4c; Table 2). Analysis of the uncharacterized protein demonstrated the lowest percent homology of all selected proteins with $23 \%$ identity to B. burgdorferi OspC (Accession ABQ42952.1) and 50\% identity to B. hermsii arthropod associated lipoprotein (Alp) (Accession GU784814.1) (Table 2) ${ }^{18}$. GlpQ had no B. burgdorferi orthologue but was $87 \%$ identical to B. hermsii GlpQ (Table 2).

The immunoreactivity of selected recombinant proteins was assessed by immunoblotting using mouse anti- $B$. miyamotoi sera collected at 8 and $40 \mathrm{dpi}$ (Fig. 5). The IgM response in serum collected from the needle inoculated mouse at $8 \mathrm{dpi}$ resulted in strong reactivity against recombinant $\mathrm{VlpC} 2(\mathrm{r}-\mathrm{VlpC} 2)$ and was comparatively weak for r-putative lipoprotein, r-GlpQ, r-VlpD9, r-VlpD1, r-VlpD2, r-VlpD10, and r-VlpD8 (Fig. 5a). In contrast, all six r-Vlps were highly IgM immunoreactive with tick bite inoculated mouse antiserum (Fig. 5b). The $r$-uncharacterized protein and $r-V s p 1$ displayed no IgM reactivity with antiserum at 8 dpi regardless of inoculation route (Fig. 5a,b). Reactivity against whole cell lysates (WCL) of B. miyamotoi (LB-2001) and B. burgdorferi (B31) was observed at 8 dpi across both needle and tick inoculated sera (Fig. 5a,b).

Antibodies present at $40 \mathrm{dpi}(\mathrm{IgG})$ recognized the entire panel of $\mathrm{r}$-Vlps, independent of infection route. Reactivity against $r$-GlpQ was present in antiserum from needle inoculated mice, while background antibody recognition was observed in tick inoculation-derived serum (Fig. 5c,d). The r-putative lipoprotein was recognized by antiserum from both needle- and tick-inoculation. Neither $\mathrm{r}-\mathrm{Vsp} 1$ nor the $\mathrm{r}$-uncharacterized protein were recognized by serum at the $40 \mathrm{dpi}$ time point (Fig. 5c,d). Additionally, the B. miyamotoi WCL was highly reactive against antibodies in both groups of serum samples. Recognition was observed, to a lesser extent, in the B. burgdorferi WCL (Fig. 5c,d).

Evaluation of cross-reactive anti-B. burgdorferi serum antibodies against recombinant $B$. miyamotoi antigens. Anti-B. burgdorferi sera from mice infected by tick bite (14 dpi) demonstrated strong cross-reactivity (IgM) with regards to all six Vlps B. miyamotoi recombinants and, to a lesser extent, r-putative lipoprotein, GlpQ, and Vsp1. No cross-reactivity was observed for the r-uncharacterized protein (Fig. 6a). IgG cross-reactivity was observed against all six recombinant Vlps with weak reactivity against Vsp1 (Fig. 6b). Both r-putative lipoprotein and $r$-GlpQ were negative for IgG cross-reactivity against antibodies present in the $B$. burgdorferi-infected murine sera (Fig. 6b). Murine sera antibodies recognized multiple proteins in the 


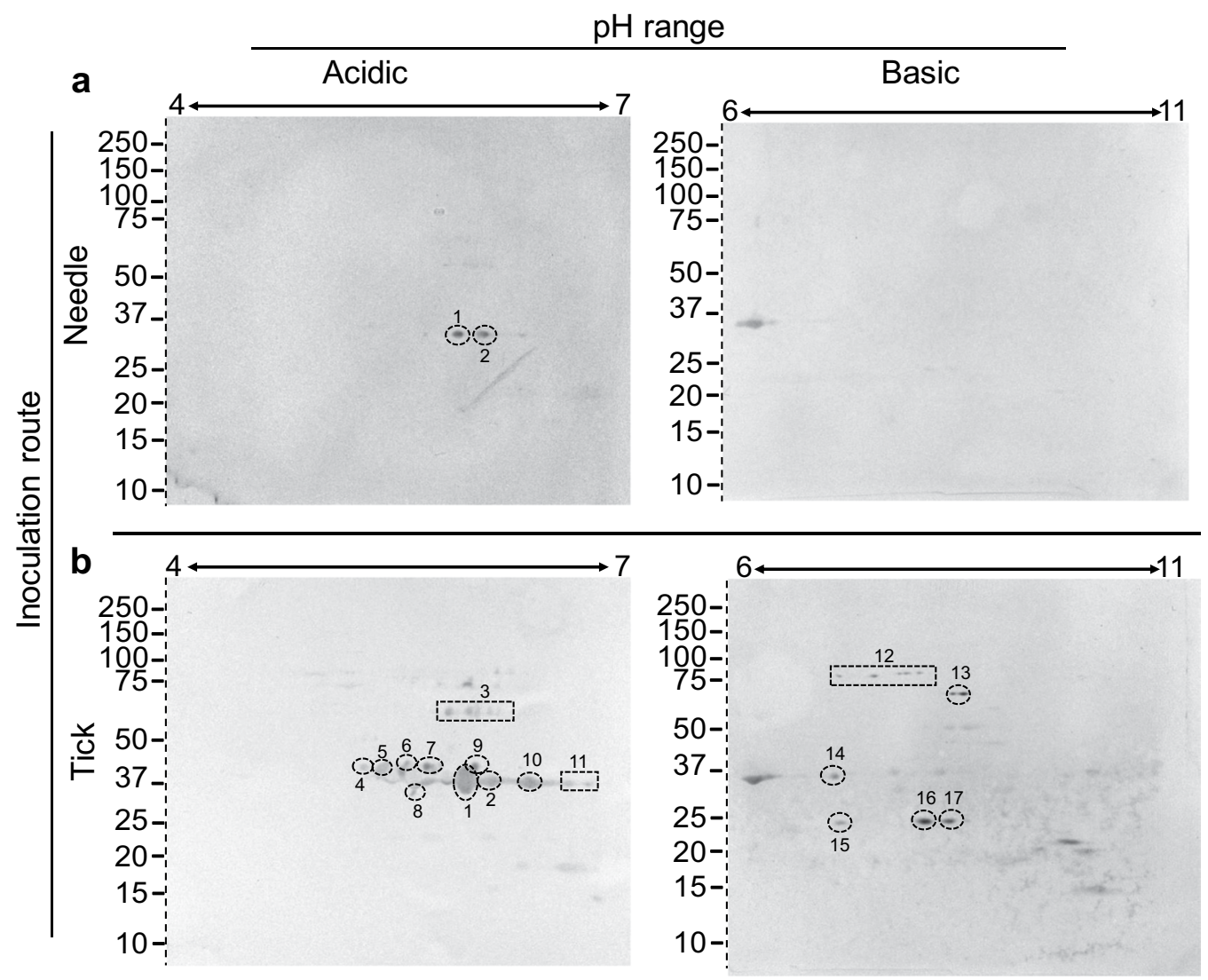

Figure 2. IgM 2DE immunoblot with sera from B. miyamotoi-infected CD1 mice collected at 8 dpi. Antigen recognition was examined in response to needle inoculation of B. miyamotoi LB-2001 (a) or through tick bite from B. miyamotoi-infected I. scapularis originating from Minnesota (b). For both sets of immunoblots an acidic ( $\mathrm{pH} 4-7)$ and basic (6-11) pH range were utilized. Sera were diluted 1:200 for immunoblotting. Immunogenic proteins spots (number 1-17) were excised from a corresponding silver stain 2DE and identified by mass spectrometry. All proteins were consistently numbered across immunoblot and time point and resulting identities from individual spots listed in Table 1 and Supplemental Table 1. Molecular weight of proteins are expressed in $\mathrm{kDa}$. Dashed lines demarcate where the gel has been cropped to exclude molecular weight markers. Uncropped blots can be viewed in Supplemental Fig. 2.

B. burgdorferi WCL and cross-reacted with multiple proteins in the B. miyamotoi WCL for both IgM and IgG (Fig. 6a,b).

Reactivity of human BMD and Lyme disease patient serum against recombinant $B$. miyamotoi antigens. A BMD patient serum sample blotted against recombinant antigens demonstrated IgG reactivity against all r-Vlps (VlpD9, VlpC2, VlpD1, VlpD2, VlpD10, and VlpD8), the r-putative lipoprotein, and r-GlpQ, but no reactivity against the $\mathrm{r}$-uncharacterized protein or $\mathrm{r}$-Vsp1 (Fig. 7a). Multi-protein reactivity was observed in the B. miyamotoi WCL but was comparatively weaker in the B. burgdorferi WCL. IgG serum antibodies from a LD patient demonstrated cross-reactivity against all $r$-Vlps but was absent for $r$-uncharacterized protein, $r$-GlpQ, and $\mathrm{r}$-Vsp1. Significantly, there was also no cross-reactivity against the r-putative lipoprotein. Both B. burgdorferi and B. miyamotoi WCLs demonstrated reactive proteins (Fig. 7b).

\section{Discussion}

Accurate diagnosis of BMD continues to warrant greater attention as the impact on human disease burden increases. Since its emergence as a human pathogen in 2011, cases have been described across multiple continents where ticks of the Ixodes genera are present, however, approaches to generate diagnostics to distinguish $B$. miyamoto $i$ infections from other borrelioses are only beginning to be investigated ${ }^{5,7,13,19-22}$. The present work took an immunoproteomic approach to compare host acute and convalescent antibody responses against B. miyamotoi infection by either needle or tick vector inoculation for the identification of novel serodiagnostic targets.

Infection in murine hosts produced differential antigen recognition patterns dependent upon infection duration ( 8 and $40 \mathrm{dpi}$ ) and inoculation route (needle vs. tick bite). IgM antibodies ( $8 \mathrm{dpi}$ ) were reactive against a number of proteins previously identified during B. miyamotoi infection including: GlpQ, Vsp1, and 9 Vlps (VlpC2, D2, D1, D8, D9, D10, 5, 15/16, and one undesignated Vlp $)^{11,14,23}$. Antibody responses to multiple Vlps suggests common epitope recognition, tandem expression, or borrelial serotype switching during acute infection. Additionally, this could also be indicative of the clonality, or lack thereof, concerning strains used for infection. 


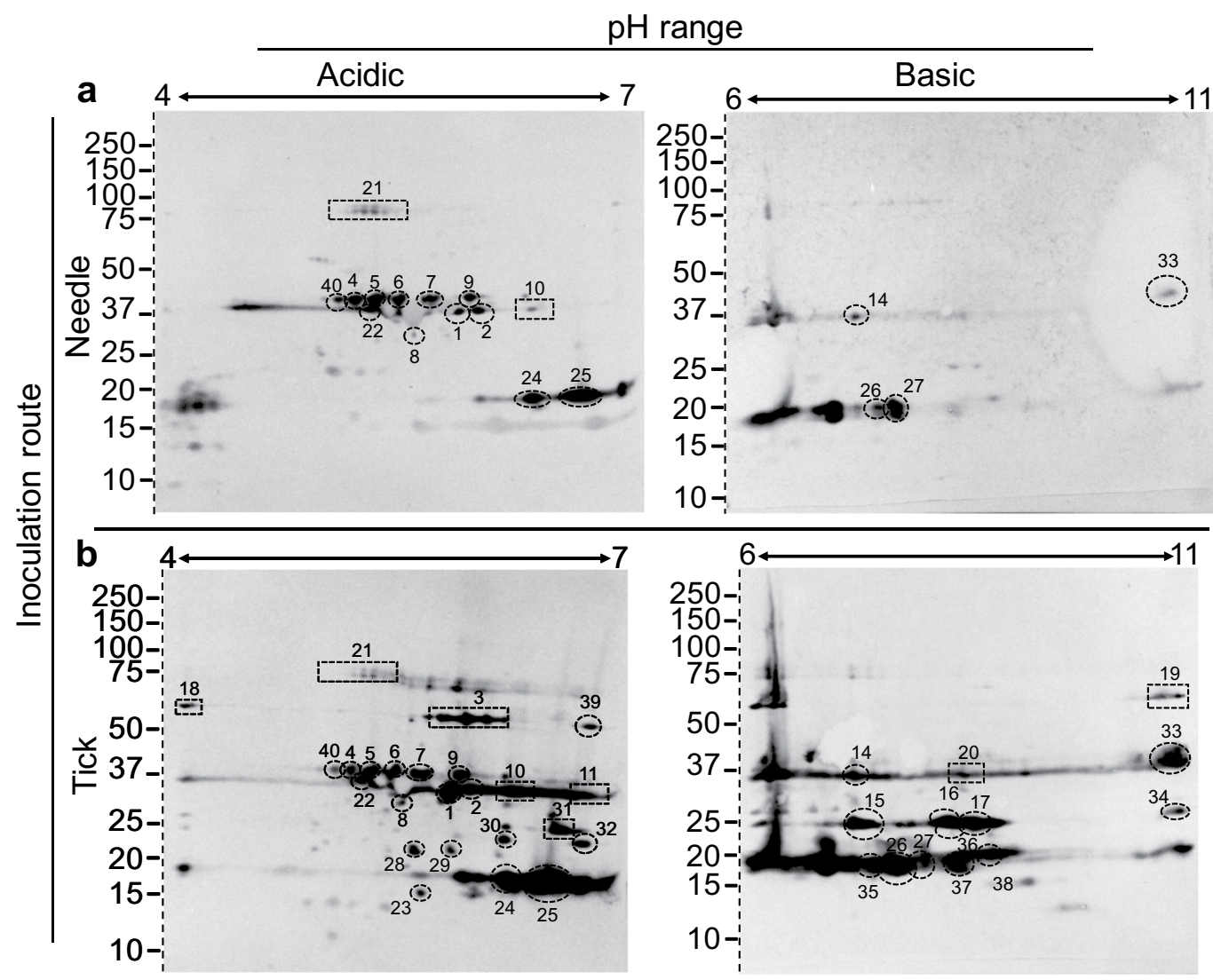

Figure 3. IgG $2 \mathrm{DE}$ immunoblot with sera from B. miyamotoi-infected CD1 mice collected at 40 dpi. Antigen recognition was examined in response to needle inoculation of B. miyamotoi LB-2001 (a) or through tick bite from B. miyamotoi-infected I. scapularis originating from Minnesota (b). For both sets of immunoblots an acidic ( $\mathrm{pH} 4-7)$ and basic (6-11) $\mathrm{pH}$ range were utilized. Sera were diluted 1:200 for immunoblotting. Immunogenic protein spots (numbers 1-11 and 14-40) were excised from a corresponding silver stain 2DE and identified by mass spectrometry. All proteins were consistently numbered across immunoblot and time point and resulting identities from individual spots listed in Table 1 and Supplemental Table 1. Molecular weight of proteins are expressed in $\mathrm{kDa}$. Dashed lines demarcate where the gel has been cropped to exclude molecular weight markers. Uncropped blots can be viewed in Supplemental Fig. 2.

Borrelia miyamotoi-infected I. scapularis used in this study originated from field collection ${ }^{24}$. Consequently, murine infection may represent a non-clonal strain of $B$. miyamotoi, contributing to the expression of multiple Vlps, which may have important implications on observed antibody response.

GlpQ, Vsp1, and multiple Vlps were again recognized at $40 \mathrm{dpi}$, suggesting their utility as serodiagnostic targets with both IgM and IgG antibody responses. A greater number of antigens were recognized by the IgG response at $40 \mathrm{dpi}$ relative to the IgM response at $8 \mathrm{dpi}$ indicating the maturity of the humoral response with time. Redundancy in protein identification from these spots was prevalent; however, unique identifications included proteins grouped with cellular components, molecular functions, biological processes, and several hypothetical proteins with unclassified function (listed in Table 1).

Immunoreactive spots were more abundant in 2DE immunoblots probed with antisera from tick bite inoculated mice compared to needle inoculated mice indicative of differential protein expression profile. Alternatively, immunoreactivity against needle inoculated B. miyamotoi LB-2001 could reflect multiple passages through SCID mice prior to stable in vitro cultivation ${ }^{25-27}$. Although there are no direct data regarding B. miyamotoi plasmid loss or gene rearrangement upon serial passage, it has been posited as an underlying reason for gene loss in at least one study ${ }^{28}$. Plasmid content representative of the strains utilized in this study was not compared but may also play a role in the observed results. However, it has been firmly established that environmental factors such as temperature and $\mathrm{pH}$, which differ in the tick versus in vitro cultivation, impact $B$. burgdorferi gene expression profiles providing rationale for investigations into gene regulation during tick transmission ${ }^{29-33}$. For example, the spots present in the immunoblots probed with antisera from tick bite inoculated mice but absent in needle inoculated mice may offer clues to determine borrelial gene products essential for survival, maintenance, and dissemination in ticks.

Assessment of various Vmps in conjunction with GlpQ to improve serodiagnosis of BMD suggests that multi-antigenic detection yields higher sensitivity and specificity ${ }^{14}$. Our data supported those findings by demonstrating recognition of r-Vlps (VlpD9, C2, D2, D10, and D8) with mouse anti-B. miyamotoi antibodies and with 


\begin{tabular}{|l|l|l|l|l|}
\hline Protein ID & $\begin{array}{l}\text { NCBI } \\
\text { accession ID }\end{array}$ & $\begin{array}{l}\text { Predicted } \\
\text { MW in kDa }\end{array}$ & $\begin{array}{l}\text { B. } \text { burgdorferi } \% \text { ID } \\
\text { (nearest protein-accession ID) }\end{array}$ & $\begin{array}{l}\text { B. hermsii \% ID } \\
\text { (nearest protein-accession ID) }\end{array}$ \\
\hline Uncharacterized protein & AOW96394.1 & 17 & $\begin{array}{l}23 \\
\text { (OspC-ABQ42952.1) }\end{array}$ & $\begin{array}{l}50 \\
\text { (Alp-GU784814.1) }\end{array}$ \\
\hline Putative lipoprotein & ALN43426.1 & 35 & $\begin{array}{l}39 \\
\text { (Putative lipoprotein-AAC67199.1) }\end{array}$ & $\begin{array}{l}\text { 62 } \\
\text { (Uncharacterized protein- } \\
\text { AHH04480.1) }\end{array}$ \\
\hline GlpQ & AOW95500.1 & 39 & $\#$ & $\begin{array}{l}87 \\
\text { (GlpQ-AAT99938.1) }\end{array}$ \\
\hline Vsp1 & AOW96329.1 & 22 & $\begin{array}{l}46 \\
\text { (OspC-AAB86545.1) }\end{array}$ & $\begin{array}{l}62 \\
\text { (Vomp-AHH04378.1) }\end{array}$ \\
\hline VlpC2 & ALU64348.1 & 35 & $\begin{array}{l}37 \\
\text { (VlsE-CAF34025.1) }\end{array}$ & $\begin{array}{l}77 \\
\text { (Vlp19-U52040.1) }\end{array}$ \\
\hline VLD2 & AOW96264.1 & 37 & $\begin{array}{l}37 \\
\text { (VlsE-AAC45764.1) }\end{array}$ & $\begin{array}{l}76 \\
\text { (Vlp42-ABO93439.1) }\end{array}$ \\
\hline VlpD1 & ALM31565.1 & 34 & $\begin{array}{l}37 \\
\text { (VlsE-CAF34025.1) }\end{array}$ & $\begin{array}{l}80 \\
\text { (Vlp-AHH13310.1) }\end{array}$ \\
\hline VlpD8 & ALU64349.1 & 36 & $\begin{array}{l}39 \\
\text { (VlsE-CAH61549.1) }\end{array}$ & $\begin{array}{l}78 \\
\text { (Vlp-ABF82178.1) }\end{array}$ \\
\hline VlpD9 & ALU64350.1 & 37 & $\begin{array}{l}39 \\
\text { (VlsE-CAH61549.1) }\end{array}$ & $\begin{array}{l}84 \\
\text { (Vlp15/16-AAB17735.1) }\end{array}$ \\
\hline VlpD10 & ALU64352.1 & 36 & $\begin{array}{l}36 \\
\text { (VlsE-CAH61549.1) }\end{array}$ & $\begin{array}{l}79 \\
\text { (Vlp-AHH13287.1) }\end{array}$ \\
\hline
\end{tabular}

Table 2. Recombinant B. miyamotoi candidate proteins IDs with associated percent identity to B. burgdorferi and $B$. hermsii. $\mathrm{Vlp}=$ variable large protein; $\mathrm{Vsp}=$ variable small protein; \# = lack of homology compared to B. burgdorferi proteins; $\mathrm{MW}=$ molecular weight; VlsE = Vmp-like sequence expressed; Alp = arthropod associated lipoprotein; Vomp = variable outer membrane protein.

human BMD antiserum. However, the Vlps were similarly recognized with antisera from B. burgdorferi-infected mice and the human LD patient suggesting that serological utility of these antigens may be compromised as a reliable diagnostic tool. The observed cross-reactivity is possibly due to orthology to B. burgdorferi proteins VlsE and OspC, and is especially notable as the $6^{\text {th }}$ invariant region (IVR6) of VlsE comprises the C6 antigen that is used extensively in diagnostic testing for $\mathrm{LD}^{16,17}$. It is noteworthy that both the $\mathrm{BMD}$ and $\mathrm{LD}$ patient serum used in this study were C6-positive. Indeed, recent reports have indicated that BMD patient serum samples react positively in C6 antigen testing ${ }^{12,34}$. Thus, previous or active infections with BMD or LD cannot be excluded for patient sera used in this or future studies where observable reactivity against Vlps or alternative antigens is noted.

Recombinant Vsp1 and the uncharacterized protein were not reactive against the mouse antisera used in the 2DE immunoblot discovery and, therefore, were not confirmed as immunogens in our mouse model. This result may be due to the presence of multiple overlapping non-immunogenic proteins identified within a single immunoreactive spot. The uncharacterized protein was most closely homologous to the $B$. hermsii Alp protein ${ }^{18}$. Like the B. miyamotoi uncharacterized protein, Alp did not elicit an antibody response in infected mice and was postulated to be associated with the tick environment. Curiously, the lack of recognition of our recombinant Vsp1 with mouse antiserum conflicted with the findings of Wagemakers et al. who described Vsp1 as an immunodominant antigen from their B. miyamotoi strain LB-2001 needle inoculated mice ${ }^{11}$. However, those investigators injected their mice with a dose of organisms 3 logs higher than that used in our study $\left(10^{7}\right.$ vs $\left.10^{4}\right)$ perhaps accounting for the observed differences. However, these researchers did observe Vmp switching from dominant expression of Vsp1 to VlpC2 in acute infection ${ }^{11}$. Our infection model resulted in dominant, acute expression of VlpC2, possibly due to Vmp switching brought about by differences in cultivation conditions or infection kinetics between studies. Similarly, we did not observe an anti-Vsp1 response from tick bite inoculated mice whereas the Wagemakers et al. study found that only 2 of 9 human BMD (presumably from tick bite infection) patient serum samples were positive for Vsp $1^{11}$. Our preliminary results demonstrated no Vsp1 reactivity in BMD or LD human sera. Though recent studies have shown its utility as a specific diagnostic marker, there could exist disparity among B. miyamotoi strains originating in North American versus Europe ${ }^{13}$. These results illustrate the complexity of differential Vmp gene expression and the corresponding role of host seroconversion dependent on inoculation route which awaits further study. Interestingly, reactivity against $r-G l p Q$ was seen by IgG in serum from needle inoculated mice at $40 \mathrm{dpi}$, and was weakly recognized in serum from mice infected by tick inoculation. This result suggests differential upregulation between inoculation routes and/or differences in antibody responses between reservoir vs. incidental (human) hosts that warrants further investigation.

The putative lipoprotein reacted strongly against the anti- $B$. miyamoto $i$ antibodies raised in both the needle and tick inoculated mice, emerging as a novel candidate serodiagnostic antigen. The putative lipoprotein has a calculated molecular mass of $35 \mathrm{kDa}$ and is encoded by a gene localized to the $\mathrm{lpD}$ plasmid of $B$. miyamotoi strain LB-200126. The homologous protein in B. miyamotoi CT13-2396 has $80 \%$ amino acid identity ${ }^{35}$ and orthologs are reported in GenBank for various RFB (including B. hermsii, B. turicatae, B. crociduriae, and B. duttonii) with amino acid identities of approximately $55 \%$ with $B$. miyamotoi. Amino acid alignment revealed regions of identity (approximately 39\%) with a B. burgdorferi putative lipoprotein. The function or role in pathogenesis of this $B$. miyamotoi putative lipoprotein is unknown. Preliminary data regarding the r-putative lipoprotein displayed background cross-reactivity in B. burgdorferi-infected mice via IgM, but not IgG. Lack of IgG response was also noted 


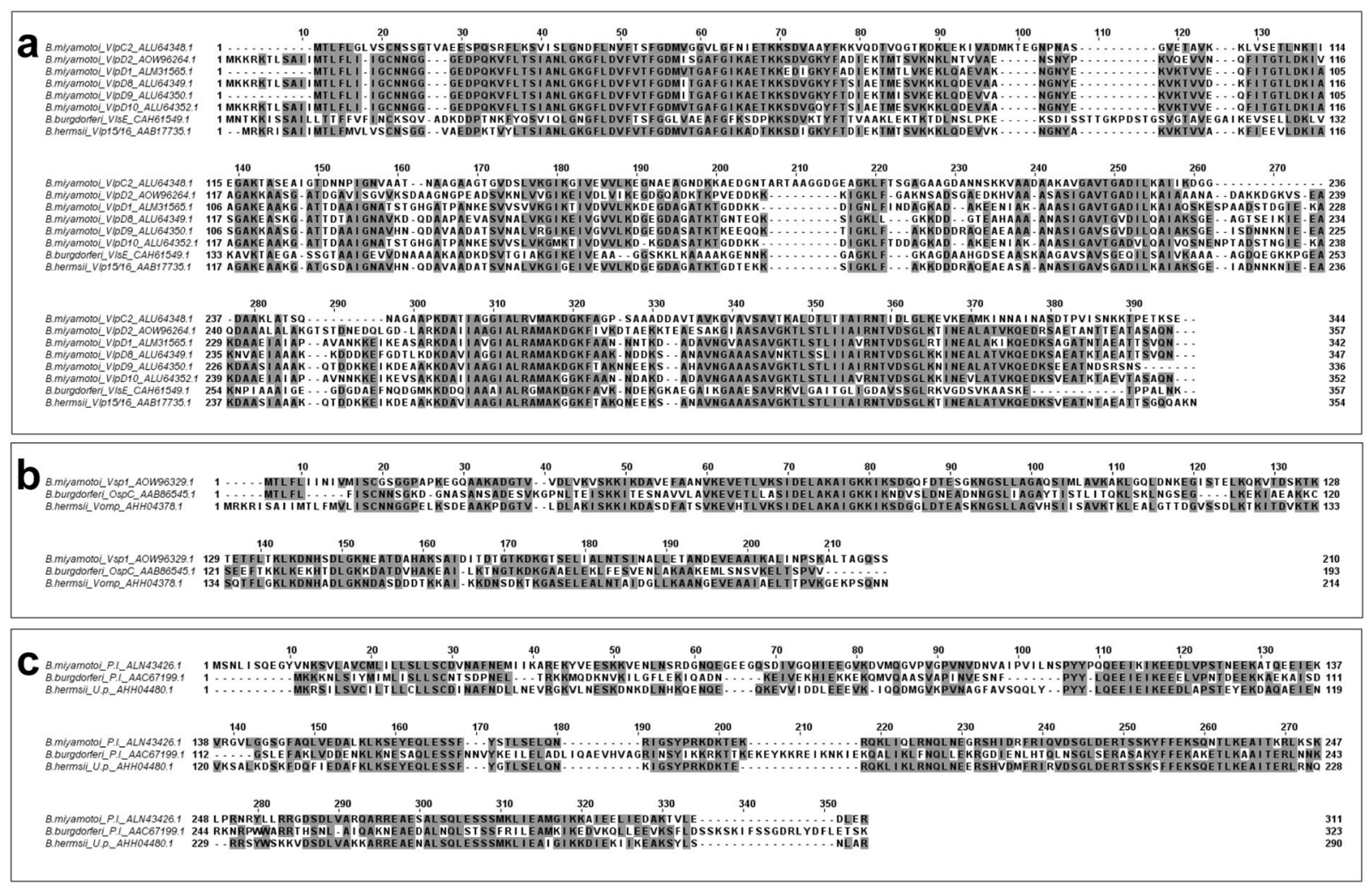

Figure 4. Multiple sequence alignment of $B$. miyamotoi proteins identified via mass spectrometry against homologous B. burgdorferi and B. hermsii proteins. (a) B. miyamotoi VlpC2, D2, D1, D8, D9, and D10 (NCBI Accession ID: ALU64348.1, AOW96264.1, ALM31565.1, ALU64349.1, ALU64350.1, ALU64352.1) against B. burgdorferi VlsE (CAH61549.1) and B. hermsii Vlp 15/16 (AAB17735.1); (b) B. miyamotoi Vsp1 (AOW96329.1) against B. burgdorferi OspC (AAB86545.1), and B. hermsii Vomp (variable outer membrane protein) (AHH04378.1); (c) Borrelia miyamotoi P.l. (putative lipoprotein) (ALN43426.1) against B. burgdorferi P.l. (AAC67199.1) and B. hermsii U.p. (uncharacterized protein) (AHH04480.1). Proteins were aligned using MUSCLE and results viewed with Jalview. Gray highlighted regions indicate areas with $60 \%$ matching amino acids across compared sequences.

in our singular LD human serum. Importantly, antibody response directed against the putative lipoprotein was dominant in the BMD convalescent human serum sample, thereby, providing preliminary evidence for serological distinction between BMD and LD. Antigenic cross-reactivity with the putative lipoprotein against antibodies directed to other RFB remains to be determined. A limitation of current work includes the number of human serum samples, especially those which are of similar infection status across disease groups (i.e. LD vs. BMD) and will be the subject of future studies. Additional human serum samples from BMD, LD, and soft tick-borne RFB patients will be necessary in the appraisal of this putative lipoprotein as a serodiagnostic target.

In conclusion, we used an immunoproteomic approach to identify B. miyamoto $i$ antigens that induce the host antibody response post-infection. Our results indicated that although Vmps are immunodominant, agreeing with other reports, antigenic cross-reactivity with anti-B. burgdorferi antibodies may be problematic. The putative lipoprotein has emerged as a potential serodiagnostic candidate to augment BMD testing with GlpQ and Vmps. Multiple proteins revealed as immunogenic in this study may aid in the development of new serodiagnostic tests for BMD.

\section{Methods and Materials}

Borrelia miyamotoi culture and mouse infections. Low passage $(\leq 4)$ B. miyamotoi strain LB-2001 ${ }^{36}$, (kindly supplied by Joppe Hovius, Center for Experimental and Molecular Medicine, Amsterdam, The Netherlands) was cultivated at $34^{\circ} \mathrm{C}$ with $5 \% \mathrm{CO}_{2}$ in modified Kelly-Pettenkofer medium (MKP-F) as previously described ${ }^{27,37}$. Spirochetes were visualized using dark field microscopy and enumerated with a Cellometer (Nexcelom, Lawrence, MA). Outbred, female CD-1 mice $(n=5)$ (Charles River, Wilmington, MA) 6-8 weeks of age were needle inoculated subcutaneously with a $100 \mu$ l suspension of B. miyamotoi $\left(1 \times 10^{4}\right)$ in MKP-F. A separate cohort of CD-1 mice $(\mathrm{n}=3-5)$ were infested with $B$. miyamotoi-infected $I$. scapularis immatures (i.e. larvae or nymphs) that originated from naturally infected female ticks collected in Minnesota that passed infection to their offspring. The tick feeding protocol was previously described ${ }^{38}$ followed by serum collection at 8 or 40 dpi. Serum from two CD-1 mice infested with nymphal B. burgdorferi (strain B31)-infected I. scapularis was collected $14 \mathrm{dpi}$ and pooled. All murine infections were performed once. Animal experiments were approved and 

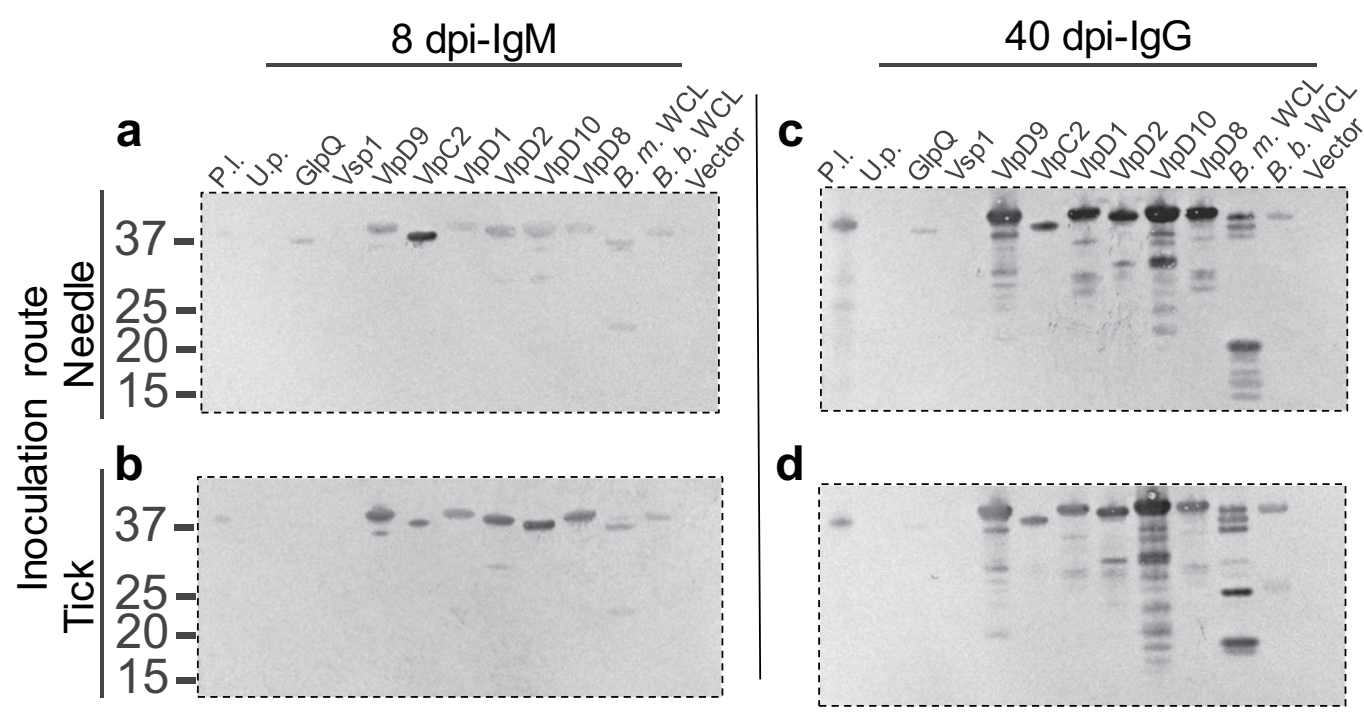

Figure 5. Validation of anti-B. miyamotoi murine antibodies against recombinant B. miyamotoi proteins $(100 \mathrm{ng})$. IgM response in CD1 mouse serum collected at $8 \mathrm{dpi}$ to needle (a) or tick (b) inoculation. IgG response in CD1 mouse serum collected at 40 dpi to needle (c) or tick (d) inoculation. All sera were diluted 1:200 for immunoblotting. Molecular weight of proteins is expressed in $\mathrm{kDa}$. P.l.=putative lipoprotein; U.p. = uncharacterized protein; Vlp = variable large protein; Vsp = variable small protein; $\mathrm{GlpQ}=$ glycerophosphodiester phosphodiesterase; $B . m$. lysate $=B$. miyamoto $i$ whole cell lysate; $B . b$. lysate $=B$. burgdorferi whole cell lysate; Vector = empty pETite expression vector. Dashed lines demarcate where the gel has been cropped to exclude molecular weight markers and portions of blots. Uncropped blots blot can be viewed in Supplemental Fig. 2.

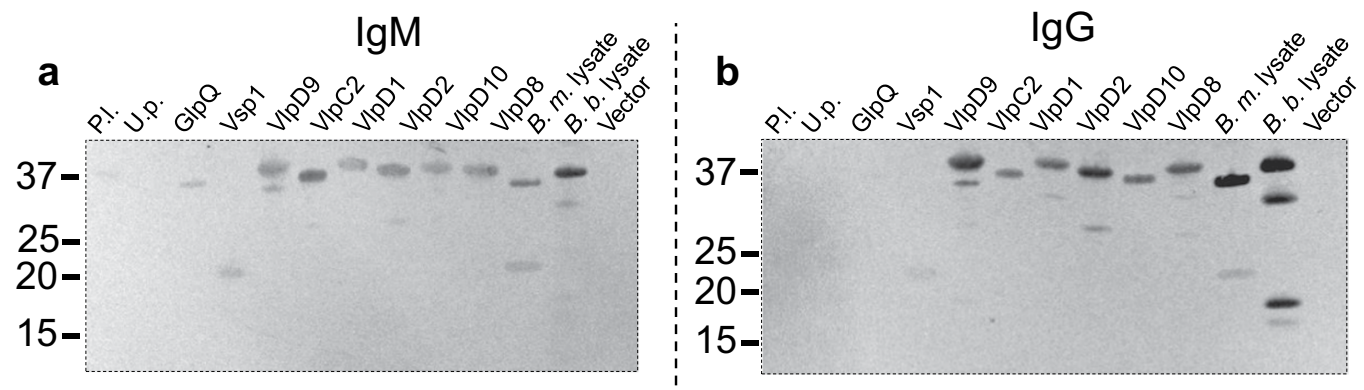

Figure 6. Evaluation of cross-reactive antibodies present in B. burgdorferi-infected CD1 mice against recombinant $B$. miyamotoi proteins $(100 \mathrm{ng}$ ). Pooled sera collected at $14 \mathrm{dpi}$ from CD1 mice exposed to $B$. burgdorferi (B31)-infected I. scapularis was assayed against B. miyamotoi recombinant proteins and an IgM (a) or IgG (b) antibody response observed. Serum was diluted 1:200 for immunoblotting. Molecular weight of proteins is expressed in $\mathrm{kDa}$. P.l. = putative lipoprotein; U.p. = uncharacterized protein; Vlp = variable large protein; Vsp = variable small protein; GlpQ = glycerophosphodiester phosphodiesterase; $B$. $m$. lysate $=B$. miyamoto $i$ whole cell lysate; $B . b$. lysate $=B$. burgdorferi whole cell lysate; Vector $=$ empty pETite expression vector. Dashed lines demarcate where the gel has been cropped to exclude molecular weight markers and portions of blots. Uncropped blots can be viewed in Supplemental Fig. 2.

conducted in accordance with guidelines and regulations as established by the Division of Vector-Borne Diseases Institutional Animal Care and Use Committee (IACUC) protocol number 16-020.

Preparation of borrelial lysate for 2DE. Mid to late log-phase Borrelia were collected via centrifugation at $4000 \times \mathrm{g}$ for $15 \mathrm{~min}$ at $4^{\circ} \mathrm{C}$ with approximately $2.6 \times 10^{8}$ spirochetes $/ \mathrm{ml}$ used as starting material for protein preparation. Bacterial pellets were washed twice in sterile $1 \mathrm{X} P B S$ and stored at $-80^{\circ} \mathrm{C}$ prior to use. Pellets were resuspended in $10 \mathrm{ml}$ of $20 \mathrm{mM}$ Tris $\square \mathrm{HCl}$ (pH 8.0) containing $30 \mu \mathrm{g}$ DNaseI (Thermo Scientific, Rockford, IL), $30 \mu \mathrm{g}$ RNaseA, and 1 Complete Protease Inhibitor (PIC) tablet (Roche Applied Sciences, Indianapolis, IN). Bacterial suspension was sonicated on ice using a Branson Sonifier 450 (Branson Ultrasonics Corporation, Danbury, CT) for $60 \mathrm{~s}$ followed by a $60 \mathrm{~s}$ rest a total of ten times using the following settings: $50 \%$ duty, output-5. The cell lysate was separated from unlysed cell debris by centrifugation at $4500 \times \mathrm{g}$ for $20 \mathrm{~min}$ at $4{ }^{\circ} \mathrm{C}$. Membrane-associated proteins were pelleted using a Sorvall WX Ultra Series ultracentrifuge (Thermo Electron Corporation) at $100,000 \times \mathrm{g}$ for $1 \mathrm{~h}$ at $4^{\circ} \mathrm{C}$ resuspended in $20 \mathrm{mM}$ Tris (pH 8.0) containing DNaseI, RNaseA, and 


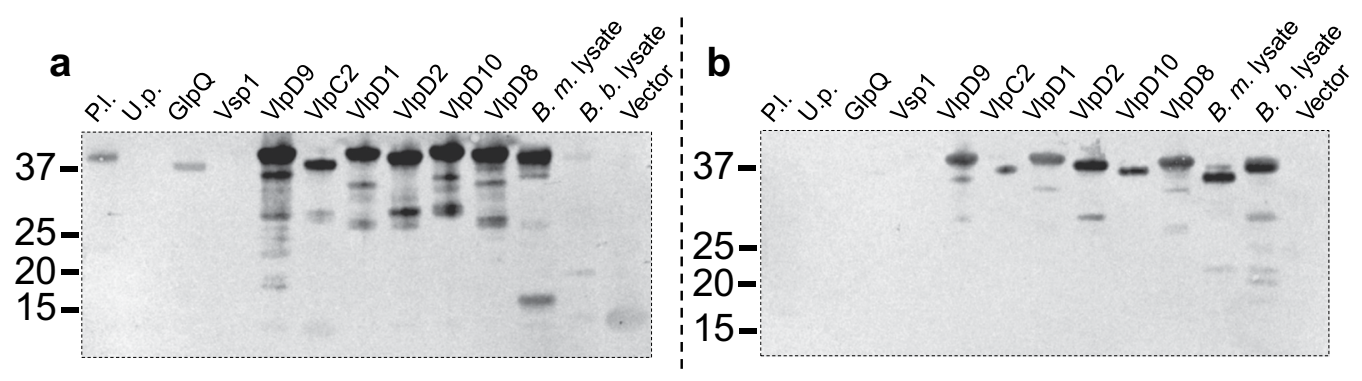

Figure 7. Evaluation of IgG reactivity to B. miyamotoi recombinant antigens (100 ng) using serum collected from a BMD patient (a), and a LD patient (b). Patient serum samples diluted 1:200. Molecular weight of proteins is expressed in $\mathrm{kDa}$. P.l. = putative lipoprotein; U.p. = uncharacterized protein; Vlp = variable large protein; Vsp = variable small protein; $\mathrm{GlpQ}=$ glycerophosphodiester phosphodiesterase; $B$. $m$. lysate $=B$. miyamotoi whole cell lysate; $B$. burgdorferi whole cell lysate; Vector $=$ empty pETite expression vector. Dashed lines demarcate where the gel has been cropped to exclude molecular weight markers and portions of blots. Uncropped blots can be viewed in Supplemental Fig. 2.

PIC (as specified above), and incubated at $4^{\circ} \mathrm{C}$ overnight $(\mathrm{O} / \mathrm{N})$. The protein suspension was dialyzed against $10 \mathrm{mM}$ ammonium bicarbonate $\mathrm{O} / \mathrm{N}$ at $4{ }^{\circ} \mathrm{C}$ in a Slide-A-Lyzer G2 cassette (Thermo Scientific, Rockford, IL) and protein concentration determined by BCA (Thermo Scientific, Rockford, IL). Protein aliquots $(100 \mu \mathrm{g})$ were lyophilized using a Labconco Freezone 4.5 (Labconco, Kansas City, MO) and stored at $-80^{\circ} \mathrm{C}$.

2DE polyacrylamide gel electrophoresis. Membrane-associated protein samples $(100 \mu \mathrm{g})$ were solubilized in $8 \mathrm{M}$ urea, $2 \mathrm{M}$ thiourea, $60 \mathrm{mM}$ DTT, $4 \%$ CHAPS, and 1\% ASB-14. Ampholytes were added to a final concentration of $0.7 \% \mathrm{pH} 4-7$ and $0.3 \% \mathrm{pH} 3-10$ for $\mathrm{pH} 4-7$ strips or $0.5 \% \mathrm{pH} 6-9$ and $0.5 \% \mathrm{pH}$ 9-11 for $\mathrm{pH}$ 6-11 strips. Samples were solubilized for 72 hours at $4{ }^{\circ} \mathrm{C}$ followed by $\mathrm{O} / \mathrm{N}$ application at room temperature (RT) to $7 \mathrm{~cm} \mathrm{pH} \mathrm{4-7} \mathrm{or} \mathrm{pH}$ 6-11 Immobiline dry strips (GE Healthcare, Piscataway, NJ). Isoelectric focusing (IEF) was performed on a GE Multiphor II (GE Healthcare, Piscataway, NJ) using the following settings: 50, 100, 150, 200,250 , and $300 \mathrm{~V}$ for 6 minutes, $500 \mathrm{~V}$ for 12 minutes, and $3000 \mathrm{~V}$ for 5 hours. Focused strips were equilibrated for 15 minutes at RT in two sequential washes of $6 \mathrm{M}$ urea, 2\% SDS, $0.05 \mathrm{M}$ Tris. $\mathrm{HCl}(\mathrm{pH})$, and $50 \%$ glycerol containing either $2 \%$ DTT or $2.5 \%$ iodoacetamide for respective incubations. Proteins were resolved in the second dimension using 4-12\% Bis-Tris SDS-polyacrylamide gels (Life Technologies, Carlsbad, CA). Gels were silver stained for protein identification (Pierce Silver Stain for Mass Spectrometry, Thermo Scientific, Rockland, IL) or transferred to nitrocellulose or PVDF for immunoblotting.

Trypsin digestion and mass spectrometry. Proteins within destained gel slices were dried in a SpeedVac (Savant, Thermo Scientific, Rockland, IL) followed by resuspension in $83 \mathrm{ng} / \mu \mathrm{l}$ of trypsin (Promega, Madison, $\mathrm{WI}$ ) in $0.2 \mathrm{M}$ ammonium bicarbonate and incubated $\mathrm{O} / \mathrm{N}$ at $37^{\circ} \mathrm{C}$. Reaction was terminated with the addition of $10 \%(\mathrm{v} / \mathrm{v})$ trifluoroacetic acid (TFA). Peptides were extracted by suspending gel slices in $0.1 \%$ TFA $/ 60 \%$ acetonitrile $(\mathrm{ACN})(\mathrm{v} / \mathrm{v})$, incubated at $37^{\circ} \mathrm{C}$ for 40 minutes, dried via SpeedVac and identified by LC-MS/MS at the Proteomics and Metabolomics Facility, Colorado State University, Fort Collins, Colorado. Peptides $(0.5 \mu \mathrm{g})$ were resuspended in $5 \% \mathrm{ACN} / 0.1 \%$ formic acid and applied to an on-line enrichment column (Waters Symmetry Trap $\mathrm{C} 18100 \AA, 5 \mu \mathrm{m}, 180 \mu \mathrm{m}$ ID $\times 20 \mathrm{~mm}$ column) with chromatographic separation via reverse phase nanospray column (Waters, peptide BEH C18; $17 \mu \mathrm{m}, 75 \mu \mathrm{m}$ ID $\times 100 \mathrm{~mm}$ column, $45^{\circ} \mathrm{C}$ ) with a 30 minute gradient: $3-8 \%$ buffer B ( $0.1 \%$ formic acid in ACN) over 3 minutes followed by $8-35 \%$ buffer B over 27 minutes at a flow rate of 350 nanoliters/minute. Peptides were injected into an Orbitrap Velos mass spectrometer (Thermo Scientific, Rockford, IL) equipped with a Nanospray Flex ion source (Thermo Scientific, Rockford, IL). A $\mathrm{m} / z$ range of $400-$ 2000 of spectra were gathered in positive mode ionization with a dynamic exclusion limit of $2 \mathrm{MS} / \mathrm{MS}$ spectra of a given $m / z$ value for $30 \mathrm{~s}$ (exclusion duration of $90 \mathrm{~s}$ ). For $\mathrm{pH} 6-11$, ions with a charge state of +2 or +3 were accepted for MS/MS. The instrument was operated in FT mode for MS detection (resolution of 60,000) and ion trap mode for MS/MS detection with a normalized collision energy set to 35\%. Resulting tandem mass spectra were extracted by ProteoWizard MsConvert (version 3.0). Spectra were searched in Mascot (Matrix Science) with a UniProt database for B. miyamotoi. No amino acid modifications were searched for proteins identified in the $\mathrm{pH}$ range of 4-7. For pH 6-11, oxidation of methionine and carbamidomethyl of cysteine amino acid modifications were viewed. Peptide and protein identities were viewed in Scaffold (version 4.8.7). Identities were accepted with a $>90 \%$ peptide and $>99 \%$ protein probability threshold and at least two unique peptides per protein identity (Supplemental Table 1). Mass spectrometry was performed for all spots at least once, with some identified twice.

Production of recombinant proteins and immunoblotting. Genes were amplified by PCR from $B$. miyamotoi genomic DNA (gDNA) using primers listed in Table 3, cloned into pETite N-His vector (Lucigen, Middleton, WI), and transformed into E. coli BL21 (DE3) according to the manufacturer's instructions. Recombinant proteins were expressed and purified using a QiaExpress Ni-NTA FastStart kit (Qiagen, Valencia, $\mathrm{CA}$ ) as described previously ${ }^{39}$. Proteins ( $100 \mathrm{ng} /$ individual protein) were transferred to PVDF membranes for immunoblotting with mouse or human serum samples (1:200), followed by incubation with alkaline phosphatase conjugated goat anti-mouse or goat anti-human IgM or IgG (1:5000) with development by NBT/BCIP with 


\begin{tabular}{|l|l|l|}
\hline Expression product & Forward primer & Reverse primer \\
\hline Uncharacterized protein & CATCATCACCACCATCACAAAGATAATGCTACTGAATAC & GTGGCGGCCGCTCTATTATGGTGCTGATAGTATGTCTCG \\
\hline Putative lipoprotein & CATCATCACCACCATCACAGTAATTTGATATCTCAGGAG & GTGGCGGCCGCTCTATTATCTTTCAAGAGTCCTCTAAAC \\
\hline GlpQ & CATCATCACCACCATCACTTTAAACAAGAAATGGGTGAAAAC & GTGGCGGCCGCTCTATTATATGAAATTCATTACTGTGTCAGT \\
\hline Vsp1 & CATCATCACCACCATCACCCGGCACCTAAGGAAGGGCAG & GTGGCGGCCGCTCTATTATGAAGATTGACCAGCAGTTAA \\
\hline VlpC2 & CATCATCACCACCATCACACTTTATTTTTAGGATTAGTG & GTGGCGGCCGCTCTATTATTCACTTTTAGTTTCAGGTGT \\
\hline VlpD2 & CATCATCACCACCATCACGGAGGGGAAGATCCACAAAAG & GTGGCGGCCGCTCTATTAGTTTTGTGCACTAGCTGTTACTTC \\
\hline VlpD1 & CATCATCACCACCATCACACTTTATTTTTAATAATAGGATGTAATAAT & GTGGCGGCCGCTCTATTAGTTTTGTACACTAGTTGTTGATTC \\
\hline VlpD8 & CATCATCACCACCATCACGGAGGGGAAGATCCACAA AAG & GTGGCGGCCGCTCTATTAGTTTTGTACACTAGTTGTTGCTTCTGC \\
\hline VlpD9 & CATCATCACCACCATCACGGAGGGGAAGATCCACAAAAG & GTGGCGGCCGCTCTATTAGTTTTGTACACTAGCTGTTACTTC \\
\hline VlpD10 & CATCATCACCACCATCACGGAGGGGAAGATCCACAAAAG & GTGGCGGCCGCTCTATTAGTTTTGTGCACTAGCTGTTAC \\
\hline
\end{tabular}

Table 3. Primers used for gene amplification for $\mathrm{pETite}$ expression vector cloning. Vsp= variable small protein; $\mathrm{Vlp}=$ variable large protein; underlined nucleotides denote sequences used for expression vector insertion.

similar approximated reaction times across all blots according to standard procedures. All recombinant protein immunoblots were performed twice.

Patient samples. Two human serum samples, obtained from New York Medical College, were from one patient with BMD and a second with LD. A case summary for the BMD patient has been published ${ }^{34}$. The BMD patient presented to the clinic approximately one month post-symptom onset with a history of tick exposure and two documented episodes of fever relapse. The blood sample tested from that clinic was positive by PCR for B. miyamotoi; the serum utilized in the current study was collected approximately 100 days after onset of the patient's symptoms (i.e. 70 days after confirmation of the diagnosis by PCR). Serologic testing for LD performed at New York Medical College was positive by the whole cell sonicate (WCS) Captia ${ }^{\mathrm{TM}}$ Borrelia burgdorferi IgG/IgM enzyme immune assay (EIA; Trinity Biotech, Jamestown, NY) and by the C6 Lyme ELISA (Oxford Immunotec, Marlborough, MA), but negative by MarDx ${ }^{\circledR}$ B. burgdorferi IgM and IgG Marblot western blots (Trinity Biotech).

The LD patient reported tick exposure and presented to the clinic with a single erythema migrans skin lesion with duration of one day. A skin biopsy was culture and PCR-positive for B. burgdorferi. Serologic testing was performed at the CDC using the WCS EIA (Vidas Lyme IgM and IgG Polyvalent Assay, bio-Mérieux, Inc., Durham, NC), the C6 Lyme ELISA (Oxford Immunotec, Marlborough, MA) and the MarDx ${ }^{\circledR}$ B. burgdorferi $\operatorname{IgM}$ and IgG Marblot western blots (Trinity Biotech). The patient was positive for LD by standard two-tiered testing (C6 ELISA/IgM western blot) and by 2-EIA criteria (WCS EIA/C6 ELISA) ${ }^{40}$. Serum was collected 22 days after the patient initiated doxycycline therapy. All methods regarding human samples were approved and carried out in accordance with the guidelines and regulations set forth by the Institutional Review Board of the Centers for Disease Control and Prevention and New York Medical College. Both patients provided informed consent.

Received: 14 June 2019; Accepted: 28 October 2019;

Published online: 14 November 2019

\section{References}

1. Krause, P. J., Fish, D., Narasimhan, S. \& Barbour, A. G. Borrelia miyamotoi infection in nature and in humans. Clinical microbiology and infection: the official publication of the European Society of Clinical Microbiology and Infectious Diseases 21, 631-639, https://doi. org/10.1016/j.cmi.2015.02.006 (2015).

2. Han, S. et al. Vertical transmission rates of Borrelia miyamotoi in Ixodes scapularis collected from white-tailed deer. Ticks and tickborne diseases 10, 682-689, https://doi.org/10.1016/j.ttbdis.2019.02.014 (2019).

3. Cutler, S. et al. A new Borrelia on the block: Borrelia miyamotoi - a human health risk? Euro surveillance: bulletin Europeen sur les maladies transmissibles = European communicable disease bulletin 24, https://doi.org/10.2807/1560-7917.Es.2019.24.18.1800170 (2019).

4. Lynn, G. E. et al. Prevalence and Geographic Distribution of Borrelia miyamotoi in Host-Seeking Ixodes pacificus (Acari: Ixodidae) Nymphs in Mendocino County, California. J Med Entomol, https://doi.org/10.1093/jme/tjx258 (2018).

5. Molloy, P. J. et al. Borrelia miyamotoi Disease in the Northeastern United States: A Case Series. Annals of internal medicine 163, 91-98, https://doi.org/10.7326/m15-0333 (2015).

6. Kadkhoda, K., Dumouchel, C., Brancato, J., Gretchen, A. \& Krause, P. J. Human seroprevalence of Borrelia miyamotoi in Manitoba, Canada, in 2011-2014: a cross-sectional study. CMAJ open 5, E690-e693, https://doi.org/10.9778/cmajo.20170070 (2017).

7. Platonov, A. E. et al. Humans infected with relapsing fever spirochete Borrelia miyamotoi, Russia. Emerging infectious diseases 17, 1816-1823, https://doi.org/10.3201/eid1710.101474 (2011).

8. Krause, P. J. et al. Borrelia miyamotoi sensu lato seroreactivity and seroprevalence in the northeastern United States. Emerging infectious diseases 20, 1183-1190, https://doi.org/10.3201/eid2007.131587 (2014).

9. Wagemakers, A., Staarink, P. J., Sprong, H. \& Hovius, J. W. Borrelia miyamotoi: a widespread tick-borne relapsing fever spirochete. Trends in parasitology 31, 260-269, https://doi.org/10.1016/j.pt.2015.03.008 (2015).

10. Krause, P. J., Fish, D., Narasimhan, S. \& Barbour, A. G. Borrelia miyamotoi infection in nature and in humans. Clin Microbiol Infect 21, 631-639, https://doi.org/10.1016/j.cmi.2015.02.006 (2015).

11. Wagemakers, A. et al. Variable Major Proteins as Targets for Specific Antibodies against Borrelia miyamotoi. Journal of immunology 196, 4185-4195, https://doi.org/10.4049/jimmunol.1600014 (2016).

12. Molloy, P. J., Weeks, K. E., Todd, B. \& Wormser, G. P. Seroreactivity to the C6 Peptide in Borrelia miyamotoi Infections Occurring in the Northeastern United States. Clinical infectious diseases: an official publication of the Infectious Diseases Society of America 66, 1407-1410, https://doi.org/10.1093/cid/cix1023 (2018).

13. Hoornstra, D., Koetsveld, J., Sprong, H., Platonov, A. E. \& Hovius, J. W. Borrelia miyamotoi Disease in an Immunocompetent Patient, Western Europe. Emerg Infect Dis 24, 1770-1772, https://doi.org/10.3201/eid2409.180806 (2018). 
14. Koetsveld, J. et al. Serodiagnosis of Borrelia miyamotoi disease by measuring antibodies against GlpQ and variable major proteins. Clin Microbiol Infect 24, 1338 e1331-1338 e1337, https://doi.org/10.1016/j.cmi.2018.03.009 (2018).

15. Barbour, A. G. Antigenic variation of surface proteins of Borrelia species. Reviews of infectious diseases 10(Suppl 2), S399-402, https://doi.org/10.1093/cid/10.supplement_2.s399 (1988).

16. Zhang, J. R., Hardham, J. M., Barbour, A. G. \& Norris, S. J. Antigenic variation in Lyme disease borreliae by promiscuous recombination of VMP-like sequence cassettes. Cell 89, 275-285, https://doi.org/10.1016/s0092-8674(00)80206-8 (1997).

17. Liang, F. T. et al. An immunodominant conserved region within the variable domain of VlsE, the variable surface antigen of Borrelia burgdorferi. Journal of immunology 163, 5566-5573 (1999).

18. Marcsisin, R. A., Campeau, S. A., Lopez, J. E. \& Barbour, A. G. Alp, an arthropod-associated outer membrane protein of Borrelia species that cause relapsing fever. Infect Immun 80, 1881-1890, https://doi.org/10.1128/IAI.06419-11 (2012).

19. Gugliotta, J. L., Goethert, H. K., Berardi, V. P. \& Telford, S. R. 3rd Meningoencephalitis from Borrelia miyamotoi in an immunocompromised patient. The New England journal of medicine 368, 240-245, https://doi.org/10.1056/NEJMoa1209039 (2013).

20. Krause, P. J. et al. Human Borrelia miyamotoi infection in the United States. The New England journal of medicine 368, 291-293, https://doi.org/10.1056/NEJMc1215469 (2013).

21. Sato, K. et al. Human infections with Borrelia miyamotoi, Japan. Emerging infectious diseases 20, 1391-1393, https://doi.org/10.3201/ eid2008.131761 (2014).

22. Sato, K., Sakakibara, K., Masuzawa, T., Ohnishi, M. \& Kawabata, H. Case control study: Serological evidence that Borrelia miyamotoi disease occurs nationwide in Japan. Journal of infection and chemotherapy: official journal of the Japan Society of Chemotherapy 24, 828-833, https://doi.org/10.1016/j.jiac.2018.06.017 (2018).

23. Schwan, T. G., Schrumpf, M. E., Hinnebusch, B. J., Anderson, D. E. Jr. \& Konkel, M. E. GlpQ: an antigen for serological discrimination between relapsing fever and Lyme borreliosis. Journal of clinical microbiology 34, 2483-2492 (1996).

24. Breuner, N. E. et al. Transmission of Borrelia miyamotoi sensu lato relapsing fever group spirochetes in relation to duration of attachment by Ixodes scapularis nymphs. Ticks and tick-borne diseases, https://doi.org/10.1016/j.ttbdis.2017.03.008 (2017).

25. Lynn, G. E. et al. An immunocompromised mouse model to infect Ixodes scapularis ticks with the relapsing fever spirochete, Borrelia miyamotoi. Ticks and tick-borne diseases 10, 352-359, https://doi.org/10.1016/j.ttbdis.2018.11.017 (2019).

26. Hue, F., Ghalyanchi Langeroudi, A. \& Barbour, A. G. Chromosome Sequence of Borrelia miyamotoi, an Uncultivable Tick-Borne Agent of Human Infection. Genome announcements 1, https://doi.org/10.1128/genomeA.00713-13 (2013).

27. Wagemakers, A., Oei, A., Fikrig, M. M., Miellet, W. R. \& Hovius, J. W. The relapsing fever spirochete Borrelia miyamotoi is cultivable in a modified Kelly-Pettenkofer medium, and is resistant to human complement. Parasites \& vectors 7, 418, https://doi. org/10.1186/1756-3305-7-418 (2014).

28. Rottgerding, F. et al. Immune evasion of Borrelia miyamotoi: CbiA, a novel outer surface protein exhibiting complement binding and inactivating properties. Scientific reports 7, 303, https://doi.org/10.1038/s41598-017-00412-4 (2017).

29. Tilly, K., Rosa, P. A. \& Stewart, P. E. Biology of infection with Borrelia burgdorferi. Infectious disease clinics of North America 22, 217-234, v, https://doi.org/10.1016/j.idc.2007.12.013 (2008).

30. Schwan, T. G., Piesman, J., Golde, W. T., Dolan, M. C. \& Rosa, P. A. Induction of an outer surface protein on Borrelia burgdorferi during tick feeding. Proc Natl Acad Sci USA 92, 2909-2913 (1995).

31. Carroll, J. A., Cordova, R. M. \& Garon, C. F. Identification of $11 \mathrm{pH}$-regulated genes in Borrelia burgdorferi localizing to linear plasmids. Infection and immunity 68, 6677-6684 (2000).

32. Carroll, J. A., Garon, C. F. \& Schwan, T. G. Effects of environmental pH on membrane proteins in Borrelia burgdorferi. Infection and immunity 67, 3181-3187 (1999).

33. Yang, X. et al. Interdependence of environmental factors influencing reciprocal patterns of gene expression in virulent Borrelia burgdorferi. Molecular microbiology 37, 1470-1479 (2000).

34. Sudhindra, P. et al. Insights into Borrelia miyamotoi infection from an untreated case demonstrating relapsing fever, monocytosis and a positive C6 Lyme serology. Diagnostic microbiology and infectious disease 86, 93-96, https://doi.org/10.1016/j.diagmicrobio.2016.06.015 (2016).

35. Kingry, L. C. et al. Toward a Complete North American Borrelia miyamotoi Genome. Genome announcements 5, https://doi. org/10.1128/genomeA.01557-16 (2017).

36. Scoles, G. A., Papero, M., Beati, L. \& Fish, D. A relapsing fever group spirochete transmitted by Ixodes scapularis ticks. Vector borne and zoonotic diseases 1, 21-34 (2001).

37. Stone, B. L. \& Brissette, C. A. Laboratory Cultivation and Maintenance of Borrelia miyamotoi. Current protocols in microbiology 42, 12f.11.11-16, https://doi.org/10.1002/cpmc.12 (2016).

38. Breuner, N. E., Hojgaard, A., Replogle, A. J., Boegler, K. A. \& Eisen, L. Transmission of the relapsing fever spirochete, Borrelia miyamotoi, by single transovarially-infected larval Ixodes scapularis ticks. Ticks Tick Borne Dis 9, 1464-1467, https://doi. org/10.1016/j.ttbdis.2018.07.006 (2018).

39. Brandt, K. S. et al. Evaluation of in vivo expressed Borrelia burgdorferi antigens for improved IgM serodiagnosis of early Lyme disease. Diagn Microbiol Infect Dis, https://doi.org/10.1016/j.diagmicrobio.2018.09.012 (2018)

40. Moore, A., Nelson, C., Molins, C., Mead, P. \& Schriefer, M. Current Guidelines, Common Clinical Pitfalls, and Future Directions for Laboratory Diagnosis of Lyme Disease, United States. Emerg Infect Dis 22, https://doi.org/10.3201/eid2207.151694 (2016).

\section{Acknowledgements}

The authors thank Joppe Hovius for providing the LB-2001 strain of B. miyamotoi. We thank Lars Eisen, James Carroll, and Kevin Brandt for helpful comments and suggestions. For providing technical advice and assistance, we also thank Bryna Fitzgerald and Sierra Mikula. This work was funded by the CDC as part of the official duties of the authors.

\section{Author contributions}

E.K.H. and R.D.G. designed the study; E.K.H., M.R.H., M.A.M.M. and J.T.B. provided technical expertise, performed experimentation, and data analysis; N.B. provided tick-exposed murine sera; G.P.W. and C.R.M. provided clinical samples and data; and E.K.H. and R.D.G. wrote the manuscript. All co-authors edited the manuscript.

\section{Competing interests}

Dr. Wormser reports receiving research grants from Immunetics, Inc., Institute for Systems Biology, Rarecyte, Inc., and Quidel Corporation. He owns equity in Abbott/AbbVie; has been an expert witness in malpractice cases involving Lyme disease; and is an unpaid board member of the American Lyme Disease Foundation. All other co-authors declare no competing interests. 


\section{Additional information}

Supplementary information is available for this paper at https://doi.org/10.1038/s41598-019-53248-5.

Correspondence and requests for materials should be addressed to R.D.G.

Disclaimer. The findings and conclusions in this report are those of the authors and do not necessarily represent the official position of the Centers for Disease Control and Prevention.

Reprints and permissions information is available at www.nature.com/reprints.

Publisher's note Springer Nature remains neutral with regard to jurisdictional claims in published maps and institutional affiliations.

(c) (i) Open Access This article is licensed under a Creative Commons Attribution 4.0 International License, which permits use, sharing, adaptation, distribution and reproduction in any medium or format, as long as you give appropriate credit to the original author(s) and the source, provide a link to the Creative Commons license, and indicate if changes were made. The images or other third party material in this article are included in the article's Creative Commons license, unless indicated otherwise in a credit line to the material. If material is not included in the article's Creative Commons license and your intended use is not permitted by statutory regulation or exceeds the permitted use, you will need to obtain permission directly from the copyright holder. To view a copy of this license, visit http://creativecommons.org/licenses/by/4.0/.

(c) The Author(s) 2019 